\title{
Africa-India nuclear cooperation: Pragmatism, principle, post-colonialism and the Pelindaba Treaty
}

\author{
Joelien Pretorius \\ University of the Western Cape, South Africa
}

\begin{abstract}
The United States-India nuclear agreement, announced in 2005, was a first step in the process to normalise India's international nuclear relations despite the fact that India is not a party to the Treaty on the Non-Proliferation of Nuclear Weapons. Africa is largely seen as a uranium supplier rather than nuclear power producer in the world nuclear order. The position that African states take towards Africa-India nuclear cooperation, uranium supply to India in particular, is informed by two seemingly contrasting factors, namely economic and political pragmatism on the one hand, and non-proliferation imperatives and norms on the other. The African Nuclear Weapons Free Zone Treaty, also referred to as the Pelindaba Treaty, prohibits uranium and nuclear-related exports to states without comprehensive safeguards of their nuclear facilities, but the case of India is still open for interpretation. Africa and India's shared post-colonial consciousness, manifesting in their historical ties, membership of the Non-Aligned Movement and South-South cooperation, is often regarded as another factor facilitating Africa-India nuclear relations. A more critical view points to the different notions of post-coloniality in Africa and India, resulting in different approaches to nuclear non-proliferation that constrain their nuclear relations.
\end{abstract}

Keywords: nuclear relations; non-proliferation treaty; India; Africa; Pelindaba Treaty

\section{Introduction}

In a joint statement on 18 July 2005, former US President George W. Bush and Indian Prime Minister Manmohan Singh announced a bilateral agreement that would normalise nuclear cooperation between their respective countries. Nuclear cooperation between the two had been restricted in 1974 and again in 1998 when India, a state that had not joined the Treaty on the Non-Proliferation of Nuclear Weapons, or simply the Non-Proliferation Treaty (NPT), tested nuclear weapons. Since the 2005 announcement of the bilateral agreement, however, a number of states and international organisations such as the Nuclear Suppliers Group (NSG) have followed the United States' lead, effectively bending the rules governing nuclear trade to normalise nuclear relations with India.

This article is directed at the question: What is the position of African states since the entry into force of the African Nuclear Weapons Free Zone Treaty, signed at Cairo in 1996, on the normalisation of nuclear relations with India, and what determines this position? In particular, it reflects on the tension between economic pragmatism and non-proliferation imperatives informing the African position, but argues that this tension is mediated by a third determinant, namely a post-colonial identity. This contribution is not an attempt to review the literature on international 
norms; however, it does assume that non-proliferation norms matter and recognises that when states choose to stretch or change them, they usually find justifications for doing so that go beyond realist interpretations of national interests. ${ }^{1}$

The article is also written with the aim to contribute to critical debate on uranium politics in Africa, which would tie into the literature cautioning against a second scramble for Africa as a result of the 'rise' of the Tiger (India) and the Dragon (China) in Africa, and globally. ${ }^{2}$

\section{India and the first grand nuclear bargain}

In almost Shakespearean fashion the background narrative to this article starts with a 'grand bargain' negotiated in the late 1960s and codified in the NPT (1970). ${ }^{3}$ Nuclear weapon states (states that had tested nuclear weapons by 1967) agreed not to provide non-nuclear weapon states (states that had not tested nuclear weapons by 1967) with nuclear weapons or facilitate the development of these weapons, and also to give up their own nuclear weapons in the future (nuclear disarmament). In turn, non-nuclear weapon states promised not to acquire or develop nuclear weapons. The inducement to give up the right to have nuclear weapons came in the form of legal assurance to non-nuclear weapon states under the NPT of an entitlement (an 'inalienable right') to civil nuclear technology. Thus, the grand bargain confirmed and codified a nuclear export norm originating in US law in the 1950s, namely to restrict nuclear exports, in the name of nuclear weapons non-proliferation, to peaceful purposes only. ${ }^{4}$ To ensure the implementation of this norm, suppliers of nuclear technology and material may export only to states with full-scope (or comprehensive) International Atomic Energy Agency (IAEA) safeguards of their nuclear programmes (Article III of the NPT). Safeguards include inspections and other verification measures to account for nuclear material. ${ }^{5}$

States that have not acceded to the NPT, which are Israel, Pakistan, and India, plus North Korea which joined and then withdrew, are denied this entitlement to nuclear technology for two reasons. Firstly, and on principle, because they did not agree to the grand bargain with the NPT members and proceeded to develop nuclear weapons, they cannot claim any privileges under the NPT; allowing them access to nuclear technology would undermine the grand bargain and may send a message to other non-nuclear weapon states that there would be no repercussions for leaving the NPT and acquiring nuclear weapons. ${ }^{6}$ Secondly, and more practically, these states do not have full-scope IAEA safeguards that would ensure that nuclear material is used only for civilian purposes and is not diverted to their military programmes.

Successive Indian leaders have chosen not to sign onto the NPT. India's position is often justified by referring to security concerns related to its adversarial relations with its northern neighbours, China and Pakistan. Indeed, India has fought wars with both these states. China tested nuclear weapons in 1964, two years after it defeated India in a border war, making it possible for China to join the NPT as a nuclear weapon state in 1992. China's initial refusal to join the NPT and its nuclear cooperation with Pakistan later (to which the guardians of non-proliferation largely turned a blind eye), did much to strengthen arguments in the domestic debate that had been waging in India since the 1950s that India should keep its options to acquire nuclear weapons open. ${ }^{7}$ Moreover, the disappointing response to India's request for explicit security assurances (that nuclear weapon states would not use or 
threaten to use nuclear weapons against non-nuclear weapon states) conveyed by a high-profile delegation to all the nuclear weapon states in 1968, also informed India's decision not to join the NPT. ${ }^{8}$

Although India's security concerns make for a powerful basis on which to reject the NPT and eventually acquire nuclear weapons, they are not convincing as the main motive for India's current nuclear stance. By India's own admission, as conveyed in a 1995 submission to the International Court of Justice (ICJ) when the latter considered the legality of the use of nuclear weapons in armed conflict: 'Nuclear weapons cannot be used in self defence ... nuclear weapons cause ... destruction which far exceeds the measure of proportionality and the object of destruction necessary and relevant to the attainment of military objectives."

India's leaders have always maintained that no state should have nuclear weapons, but if any state has, India must have the same right too. ${ }^{10}$ The nuclear weapon states' thwarting of their nuclear disarmament obligations under Article VI of the NPT did much to support India's claim that the NPT is an instrument of those states that had tested nuclear weapons before 1967 to freeze an unfair nuclear order in their favour. ${ }^{11}$ The term 'nuclear apartheid' was first coined by Indian negotiators at the NPT deliberations in the 1960s to describe this state of affairs, and has often been employed by Prime Minister Manmohan Singh to justify India's nuclear stance post-1998. ${ }^{12}$

However, nothing in India's nuclear policy today suggests that India would prefer a world where all states are entitled to nuclear weapons. Rather, India seems to view nuclear weapons as a symbol of great power status to which it holds a claim. ${ }^{13}$ Manmohan Singh reversed India's position toward the NPT in 2009, stating that India would join the NPT, but as a nuclear weapon state. ${ }^{14}$ It thus seems that India views the NPT as somehow knighting the nuclear weapon states as 'responsible' enough to have nuclear weapons and non-nuclear weapon status as second tier. ${ }^{15}$ This is not contrary to the nuclear weapon states' own interpretation of the NPT and the rationale that the Bush administration provided for the US-India agreement to win over domestic and international audiences. ${ }^{16}$

Although India has remained outside a number of nuclear non-proliferation treaties, it has not proliferated 'horizontally' in the sense that Israel, North Korea and Pakistan have been accused of doing. ${ }^{17}$ Horizontal proliferation refers to the transfer of nuclear weapons or material to another state or non-state entity, whereas vertical proliferation is the expansion or renovation of a nuclear weapon state's own arsenal.This sets India apart from other de facto nuclear weapon states and grounds India's self-image as a 'responsible nuclear weapon state' that should enjoy the prestige and privileges of the other nuclear weapon states.

India diverted nuclear technology acquired from the United States, France and Canada to its military sector and tested weapons twice: in 1974 and in 1998. ${ }^{18}$ The 1974 test led to the suspension of all nuclear cooperation with India and sanctions, and it was under US pressure that Prime Minister Indira Ghandi cancelled another test she had planned for $1983 .{ }^{19}$ India's 1998 tests were again followed by US and international condemnation. The Clinton administration recalled its ambassador from India and relations between the countries reached a post-Cold War low. India rekindled US-India relations as soon as possible, however, realising that in order to gain global recognition India needed to be recognised as a legitimate nuclear weapons state and in order to do this, relations with the US needed to be mended.'20 


\section{India and the Nuclear Suppliers Group}

By 2011, India is widely perceived as a rising global power, often compared with China. Attributed to the financial reforms instituted by Manmohan Singh and India's impressive information technology sector that expanded rapidly after the Cold War, the nation's rise is characterised by high economic growth, increased foreign trade and investment, and increased household income. ${ }^{21}$ Coupled with its population size (at 1.2 billion, second only to China's), however, India's rapid development has resulted in formidable energy challenges. India's policymakers are thus pursuing all sources of energy provision, not least nuclear energy. In this regard, the Indian nuclear energy market has become a coveted sector for international exporters and investors. ${ }^{22}$

The most prominent international forum for the cultivation of nuclear export controls is the Nuclear Suppliers Group (NSG), which was formed in 1975 and has a membership now numbering 46 nuclear technology and material supplier states. ${ }^{23}$ The NSG's self-imposed mission is to align 'the interrelated objectives of preventing the proliferation of nuclear weapons, and the promotion of international trade and co-operation in the peaceful uses of nuclear energy. ${ }^{, 24}$ The NSG's creation and phases of growth were spurred on by cases where nuclear exports for peaceful purposes were diverted to military purposes. It is not by accident that the NSG was formed subsequent to India testing a nuclear weapon in 1974 - a test made possible by diverting civilian technology sourced internationally to military purposes. Subsequently, when the extent of Iraq's nuclear weapons programme, which grew under the guise of peaceful purposes, became known in the wake of the first Gulf War in 1991, the NSG experienced a revival. In practice, the NSG makes rules by consensus on what 'dual-use' technologies may or may not be exported (compiling a 'trigger list'), and also to whom. ${ }^{25}$ The NSG guidelines for nuclear exports correspond with the NPT's requirement for nuclear exports to non-nuclear weapon states, namely that recipient states must allow full-scope safeguards on their nuclear facilities. ${ }^{26}$

\section{India's second grand nuclear bargain: The 2005 US-India nuclear agreement}

The 2005 Bush/Singh announcement of a bilateral cooperation plan between the United States and India included nuclear energy and implied the normalisation of nuclear trade between the two countries. With this agreement, the United States labelled India as a responsible state with advanced nuclear technology that should be given the same benefits and responsibilities as other such states. In essence, the Bush administration had recognised India as a nuclear weapon state. ${ }^{27}$ More specifically, the United States conferred this status upon India by promising to work toward full civil energy cooperation, seeking agreement to amend US laws and policies, to amend international regimes to enable civil nuclear energy cooperation and trade with India, and to encourage the normalisation of nuclear energy relations with India by US partners and in other forums. The latter includes the International Thermonuclear Energy Reactor (ITER) project, which explores nuclear fusion for energy production. On the Indian side, Prime Minister Singh committed India to the following: identifying and separating civilian and military nuclear facilities and notifying the IAEA of civilian facilities, which would also be placed under voluntary IAEA safeguards and the IAEA Additional Protocol; continuing a unilateral moratorium on nuclear testing; cooperating with the 
United States towards a multilateral Fissile Material Cut Off Treaty; refraining from exporting enrichment and reprocessing technologies to states not in possession of these technologies, and joining international efforts to limit their dissemination including through comprehensive export control legislation and through adherence to the Missile Technology Control Regime (MTCR) and the NSG guidelines. ${ }^{28}$

The agreement was received in a positive light by some. Mohammed ElBaradei, Nobel Laureate and former director-general of the IAEA, suggested that the normalisation of nuclear trade with India under certain conditions would bring India into the non-proliferation regime, albeit without joining the NPT. ${ }^{29}$ The IAEA subsequently negotiated a 'type 66 safeguard agreement' with India that would cover India's civilian nuclear facilities, but not its military nuclear facilities. Under the agreement, India will put additional civilian facilities under IAEA safeguards to comply with the conditions that would allow the IAEA members to provide India with access to the international nuclear fuel market. The agreement also makes clear that India can 'take corrective measures' should international fuel supply for its civilian reactors be disrupted. ${ }^{30}$ It has been argued that these unspecified corrective measures could include unilateral withdrawal of civilian facilities from IAEA safeguards should India's access to nuclear fuel be suspended, for instance in response to an Indian nuclear test. ${ }^{31}$

The agreement with the IAEA is not a full-scope safeguards agreement, because it excludes India's military nuclear facilities. For this reason, the NSG had to make an exception to its rules to allow its members to export nuclear material to India. The NSG passed a 'once-off' waiver to its rules that would allow normalisation of nuclear trade with India under certain conditions, for example assurance of a unilateral moratorium on nuclear testing. The NSG waiver was a precondition for the US-India agreement to be passed by the US Congress. Other states have followed suit after the NSG exception was granted, for example Canada, France and Russia have all concluded separate agreements to normalise nuclear trade with India. To reach the point at which the NSG agreed to the waiver was no easy route. Although some NSG members saw the economic benefits of nuclear cooperation with India for their own nuclear industries, others asked tough questions about the precedent that the waiver would be setting. These NSG members would probably not have acquiesced to the waiver without intense US and Indian lobbying, recognition of India's past horizontal non-proliferation record, and India's assurance of a nuclear testing moratorium. ${ }^{32}$

The US-India agreement has nevertheless caused a storm in the nonproliferation and arms control community. Their concern is that the agreement undermines the nuclear non-proliferation regime by watering down nuclear export restrictions. By allowing uranium exports to India for civilian uses, the agreement frees up India's domestic nuclear fuel stocks for military use. They also argue that bending the rules for India will induce an arms race in the region as Pakistan and China increase their nuclear arsenals in response to increased Indian capacity. It is feared that the agreement sends 'the wrong message' to would-be proliferators that there are no lasting consequences for disregarding the non-proliferation regime. Or, worse, normalising nuclear relations with India could be perceived as a double standard favouring US allies, and serve as a precedent for similarly recognising and legitimising Israel's nuclear weapon status. ${ }^{33}$

The foregoing narrative on the US-India nuclear agreement, describing how it involved the IAEA and the NSG and the concerns it raises, is by no means a 
comprehensive account. Rather, it is an overview to arrive at an understanding of the significance of exploring Africa-India nuclear cooperation. Similar to other states in other regions, African states individually or collectively will be adopting a position on the normalisation of nuclear relations with India. If foreign policymaking is interpreted as a rational choice process that involves a cost-benefit analysis of 'to normalise or not to normalise nuclear trade', the scales would be weighed down by economic pragmatism, on the one hand, and non-proliferation imperatives on the other. The next section will explore the tension between these often competing factors.

\section{Africa-India nuclear cooperation: Economic pragmatism and the political-economy of global uranium supply}

A report by the World Nuclear Association (WNA) notes that India intends to provide $25 \%$ of its electricity supply via nuclear energy by $2050 .{ }^{34}$ Even contemplating this dramatic increase in nuclear energy production in India is only possible because the normalisation of nuclear trade includes access to uranium sources outside India. Prior to the NSG waiver, India was suffering severe uranium shortages, already referred to as 'a major problem' in $2005 .{ }^{35}$ By 2007 , the uranium stockpiled prior to the spike in India's energy needs was nearing depletion. India's domestic uranium mining capacity was estimated at about 300 tons per year, while its civil and military needs were estimated at 600 tons per year in $2007 .{ }^{36}$ The stateowned Nuclear Power Corporation of India Limited (NPCIL) puts India's uranium needs at 8000 tons of uranium per year by 2035, a 10 fold increase from the current situation. ${ }^{37}$ However, due to health and environmental concerns, opening new uranium mines in India has been met with domestic resistance. ${ }^{38}$

This is where Africa fits into the picture - as a uranium supplier with close to $20 \%$ of the world's recoverable uranium. ${ }^{39}$ Namibia, Niger and South Africa have an estimated $94 \%$ of the uranium on the continent and these countries, along with smaller potential suppliers, such as Malawi, are well-positioned to meet India's uranium needs. ${ }^{40}$ In fact, prior to the NSG waiver, India had already courted African states for uranium mining and exploration agreements as an alternative to supply from Canada, Australia and Kazakhstan (all of them NSG members that were not allowed to sell uranium to India at the time). ${ }^{41}$ In 2007 an Indian company won a tender for uranium exploration in Niger, a milestone for a state so isolated in the nuclear order. The Hindu, one of India's largest daily newspapers, reported on the tender victory as follow: 'Niger is not a member of the Nuclear Suppliers Group, the 45-member nation that controls all nuclear-related commerce, and hence it should be easy for India to access the uranium once the mines become operational this will take several years. ${ }^{42}$ Officials in Niger hailed the granting of mining permits to Indian (and Chinese) companies by saying that it would end France's monopoly on uranium mining in that country. ${ }^{43}$ Similar agreements or intentions for such agreements followed from Gabon in 2008, ${ }^{44}$ Namibia in $2009^{45}$ and Malawi in 2010 . $^{46}$

The NSG waiver has of course made it easier for India to obtain uranium, but the African mining and prospecting agreements are still significant and a deliberate strategy of India to ensure future uranium supply. The NPCIL's finance director was quoted as saying that the company's strategy is to 'buy stakes in mines and tie up the source of supply'. ${ }^{47}$ Although evidence of any official Indian request to the 
South African government to buy uranium is elusive, Indian press reports claim that the NPCIL has considered taking up an offer of minority stakes in four African uranium mines owned by Areva SA, the African arm of the French state-owned nuclear power company. ${ }^{48}$

Allowing Indian investment in uranium mining, and consequently access to Africa's uranium, is regarded as an economically pragmatic position on the issue of normalisation of nuclear cooperation with India, based on the economic benefits that would flow from this. However, the fungibility of uranium also drives a pragmatic approach. ${ }^{49}$ Even if African states decide to block India from direct access to its uranium, India may still benefit indirectly from African uranium on the world market. For instance, through a tripartite agreement Russia, the United States and France have committed to provide life-time fuel supply for reactors sold to India. Russia and France are both major uranium mining states in Africa and could thus use uranium sourced from their African mining endeavours for this end. ${ }^{50}$ Even if African states exercise their prerogative to prohibit these countries from exporting African-sourced uranium to India as a requirement of third party assurance from a recipient state, the African uranium entering the world market will free up uranium from other countries that have nuclear cooperation agreements with India. Sandy Gordon avers, for example, that Australia's decision not to sell uranium to India will have little material effect on India's access to uranium so long as India is accorded access to world markets and Australia continues to sell into those markets. ${ }^{51}$

Not all African states have opted for the pragmatic approach outlined above. Reminded that the Manhattan Project (which resulted in the bombs dropped on Japan in the 1940s) was largely fuelled by uranium from the Shinkolobwe mine in what is today the Democratic Republic of the Congo (DRC), African states are aware of the dual use of their uranium. Some African states are concerned about the precedent that the Indian case sets for non-proliferation and disarmament. On principle therefore, African states may decide not to normalise nuclear relations with India, guided by their obligations under the NPT, the Pelindaba Treaty, and their domestic legislation.

\section{Africa's non-proliferation imperatives and the Pelindaba Treaty}

The Pelindaba Treaty ${ }^{52}$ stands out as the legal instrument to guide an African position on normalisation of nuclear relations with India for two reasons. Firstly, among African states only South Africa is a member of the NSG, thus the India waiver (which NSG members see as superseding their NPT obligations) would be applicable only to South Africa's relations with India. Secondly, and perhaps more importantly, the Pelindaba Treaty reflects an Africa specific view on non-proliferation within the context of an African security community. ${ }^{53}$ The Pelindaba Treaty is in a more general way an important source of law for African states that should trump or be encoded in their domestic legislation once they have ratified it.

The Pelindaba Treaty, to review, establishes the African Nuclear Weapons Free Zone (ANWFZ). African states have pursued such a treaty since France tested nuclear weapons in 1960 in what was then French Algeria. The United Nations General Assembly (UNGA) shortly afterwards adopted Resolution 1652, calling on all states to 'consider and respect the African continent as a denuclearized zone' ${ }^{54}$ The Organisation of African Unity (OAU), at its first summit held in Egypt in 1964, 
adopted the Cairo Declaration on the Denuclearization of Africa. ${ }^{55}$ OAU members expressed their readiness to commit to an Africa free of nuclear weapons through a treaty, but it was not until three decades later that progress was made towards such a treaty.

Through these years, South Africa's domestic policy of apartheid and its consequent international pariah status was one of the main obstructions to an ANWFZ. South Africa refused to join the NPT and had developed the capability to enrich uranium by 1970. South Africa followed a policy of deliberate nuclear ambiguity similar to that of Israel (with whom the apartheid government had strong military ties at the time), not admitting or denying that it had nuclear weapons. ${ }^{56}$ As international outcasts, South African policymakers intended to use nuclear weapons to blackmail Western states into coming to the country's rescue should South Africa ever face a Soviet Union-driven communist 'onslaught' by states in Southern Africa. ${ }^{57}$ When the Cold War ended in the early 1990s, and in the face of fierce opposition from a majority of the South African population, the apartheid government's anti-communist rhetoric could no longer justify a racially oppressive regime and negotiations toward a democratic transition began. However, before the regime changed, the apartheid government proceeded to dismantle its six nuclear weapons and acceded to the NPT in 1991 as a non-nuclear weapon state. At that point, the OAU and UN appointed a joint expert group to write the draft text of an ANWFZ treaty. South Africa joined the OAU in 1994 after its first democratic elections and, in 1996, the Pelindaba Treaty ${ }^{58}$ was opened for signature. ${ }^{59}$ On 15 July 2009 , the treaty came into effect with the $28^{\text {th }}$ ratification. $^{60}$

All 53 African states have signed the treaty, but at the time of writing 22 still needed to ratify it. ${ }^{61}$ In some cases states are simply not ratifying the treaty because of weak governmental structures or internal instability. Arguably this is true for Somalia. In other cases, the choice to withhold ratification is a political decision. Egypt, for example, has made acceptance of any further nuclear arms control measures conditioned on Israel acceding to the NPT as a non- nuclear weapon state (a point that will be returned to later). ${ }^{62}$ However, other African states hesitate on economic grounds. Article 18 of the Vienna Convention on the Law of Treaties provides the following: 'A State is obliged to refrain from acts which would defeat the object and purpose of a treaty when: (a) it has signed the treaty ... until it shall have made its intention clear not to become a party to the treaty.' Thus, it will be illegal for signatories to the Pelindaba Treaty, such as Namibia and Niger, to export uranium to India if the Pelindaba Treaty determines it so. ${ }^{63}$ Both the letter and spirit of the Pelindaba Treaty are indicative in this regard.

\section{The letter of Pelindaba}

In terms of the letter of the Pelindaba Treaty, Article 9 that relates to 'Verification of peaceful uses' is clear. Each party undertakes:

(a) to conduct all activities for the peaceful use of nuclear energy under strict non-proliferation measures to provide assurance of exclusively peaceful uses; (b) to conclude a comprehensive safeguards agreement with IAEA for the purpose of verifying compliance with the undertakings in subparagraph (a) of this article; and 
(c) not to provide source or special fissionable material, or equipment or material especially designed or prepared for the processing, use or production of special fissionable material for peaceful purposes to any non-nuclearweapon state unless subject to a comprehensive safeguards agreement concluded with IAEA.

The article's intent conforms to non-proliferation norms in general by calling each party to engage only in the peaceful use of nuclear energy under strict nonproliferation measures that include comprehensive IAEA safeguards as the verification instrument. Article 9(c) conforms to nuclear export restrictions by prohibiting the transfer of source or special material (even if designed for peaceful purposes) to a non-nuclear weapon state unless the latter is subject to a comprehensive IAEA safeguards agreement. Seen in terms of 9(a) and 9(b), 9(c) can be interpreted to codify the responsibility incumbent on each party not to facilitate, knowingly or unknowingly, the proliferation of nuclear weapons. According to a strict interpretation of Article 9(c), there is no question of whether it is legal for member states of the Pelindaba Treaty to engage in nuclear cooperation with India: it most definitely is not.

However, there is another 'minimalist' interpretation of the Pelindaba Treaty, namely that the type 66 IAEA safeguard agreement with India complies with Annex II paragraph 3 of the treaty, which refers to the safeguards that member states have to sign with the IAEA. ${ }^{64}$ That provision states: 'For the purpose of this Treaty, the safeguards referred to in paragraph 1 above shall have as their purpose the verification of the non-diversion of nuclear material from peaceful nuclear activities to nuclear explosive devices or for purposes unknown.' If this restricted meaning of a safeguard agreement is extended to what is expected of recipient states, the Indiaspecific IAEA safeguard agreement arguably meets this requirement, as it establishes verification of non-diversion from India's civil to military programmes. Using this interpretation to legalise uranium exports to India would however seem rather a disingenuous attempt to evade Article 9(c)'s explicit prohibition of uranium exports to states without comprehensive safeguards.

\section{The spirit of Pelindaba}

To determine whether uranium exports to India would be in breach of the Pelindaba Treaty, it is also necessary to look at the context of the treaty, which gives insight into the spirit rather than the letter of the treaty. ${ }^{65}$ Firstly, the Pelindaba Treaty takes its cue from other nuclear weapons free zone (NWFZ) treaties. The object and purpose of the treaty is firstly to address a regional security issue, in that it is an important part of the overall peace and security architecture of the African Union: is indeed one of the building blocks of the Common African Defense and Security Policy (CADSP)'. ${ }^{66}$ NWFZs provide common security through a doctrine of mutually assured abstinence from nuclear weapons, rather than deterrence through mutually assured destruction by nuclear weapons. Abstinence from acquiring or developing nuclear weapons is verified under the IAEA safeguards system.

Secondly, the ANWFZ is seen as 'an integral part of a planned integrated approach to the Treaty Zones towards disarmament and nuclear nonproliferation. ${ }^{97}$ When the Pelindaba Treaty entered into force, the Southern Hemisphere became a nuclear weapons free zone (excluding international waters). ${ }^{68}$ 
In fact, when the African Union (AU), the OAU's successor, entertained an agenda item on the status of the Pelindaba Treaty in 2006, members were encouraged to ratify the treaty precisely because its delayed entry into force was seen as the weak link in a network of NWFZs. ${ }^{69}$ The integrated approach is founded on the philosophy that NWFZs are not an end in themselves but a means for achieving a world without nuclear weapons. ${ }^{70}$ The focus is not only regional, but how each NWFZ becomes a building block of the bigger goal. The Pelindaba Treaty reflects this philosophy in the preamble and protocols where it notes: 'the need to take all steps in achieving the ultimate goals of a world entirely free of nuclear weapons, as well as of the obligation of all States to contribute to this end.' Although the treaty emphasises the right to peaceful nuclear technology and its use for the development of the continent, the overriding spirit of the treaty is clearly to create an African continent free of nuclear weapons and by doing so to contribute to global nuclear disarmament.

However, the treaty's object and purpose are not limited to military security, but are aligned with what has come to be known as human security, commonly defined as a situation of 'freedom from fear and freedom from want'. ${ }^{71}$ The argument is based on a human-centred approach to international security that hails the health and environmental benefits of a NWFZ. The Pelindaba Treaty Preamble claims a determination 'to keep Africa free of environmental pollution and other radioactive waste', ${ }^{72}$ and also contributes to human security by promoting mutually assured abstinence wherein there would be no need to spend resources on costly nuclear weapon programmes. The notion that NWFZs prevent the use of resources for military means that could be used for development is commonly expressed. For example, the Treaty of Tlatelolco explicitly states this conviction in its preamble: 'Convinced ... that the military denuclearization of Latin America and the Caribbean ... will constitute a measure which will spare their peoples from the squandering of their limited resources on nuclear armaments...'. Similarly, Ambassador Alfredo Labbe, Director of International and Human Security of Chile, at the 2010 NPT Review Conference, made the following statement in relation to NWFZs: 'We are convinced of the benefit that the use of the resources devoted to nuclear weapon programs could have for humanity if they were utilized for supporting social and economic development'. ${ }^{73}$

The Pelindaba Treaty also claims entitlement to the peaceful use of nuclear technology for socio-economic development (Article 8(2)), calling for mechanisms of nuclear cooperation to be established and strengthened. One of the mechanisms already in existence is the African Regional Cooperation Agreement for Research, Development and Training related to Nuclear Science and Technology (AFRA). ${ }^{74}$ The treaty in this way invokes the 'grand bargain' that was made between nuclear weapon states and non-nuclear weapon states when the NPT was negotiated: the NPT's Article IV(1) refers to the 'inalienable right' to nuclear energy for peaceful uses and Article IV(2) obliges states to cooperate to this effect with specific consideration for the 'needs of the developing areas of the world'. ${ }^{75}$ Furthermore, the Pelindaba Treaty encourages links with other international and continental nuclear non-proliferation organisations to harness nuclear technology for development. These organisations include the IAEA, the Comprehensive Test Ban Treaty Organization (CTBTO) and AFRA.

In this respect, it could be argued that India-Africa civilian nuclear cooperation has the potential to promote the Pelindaba Treaty's goal of reaping the economic 
benefits of nuclear energy for development. Discussion will return to this point below, in examining whether uranium mining and exports actually serve to promote or hinder human security in Africa.

It seems that the interpretation of the Pelindaba Treaty with respect to normalisation of nuclear trade with India is at this point left open. This can be attributed to the fact that the treaty entered into force as recently as 2009 , and the member states and civil society groups that encouraged its entry into force do not want to introduce controversy as yet. Indeed, the verification instrument, the African Commission on Nuclear Energy (AFCONE), was only established in October 2010. Should African member states prefer a consensus interpretation of the India case, AFCONE would be the appropriate organ for this discussion. What has transpired, though, is that Egypt's linking of its ratification of the treaty to Israel's signing on to the NPT as a non-nuclear weapon state is affecting the development of this discussion. Egypt is concerned that the India exemption may become a precedent for normalisation of Israel's nuclear status, and hence finds the India case problematic. This has especially come to the fore and informed a more conservative and cautious approach to India by African states during the NPT Review Conference in 2010. The position that South Africa is taking on the issue further illustrates its complicated nature.

\section{South Africa's position vis-à-vis India}

As the only African NSG member, South Africa's position warrants special attention. Not only has South Africa supported the exception that the NSG made for India, but South African politicians have on several occasions expressed willingness to engage in civil nuclear cooperation with India, especially in bilateral visits between the two countries. Moreover, the mooted investment by the NPCIL in Areva SA would particularly link India to uranium mining in South Africa. However, it seems that a much more cautious South African approach is emerging towards nuclear cooperation with India. ${ }^{76}$ This conclusion is supported by the fact that South Africa's nuclear energy legislation prohibits exports to states without full-scope IAEA safeguards, and no real effort to change this law has emerged since the NSG waiver was passed in 2008. No bilateral agreement on nuclear cooperation has been signed between the countries either. A possible explanation for this may be that some South African officials are of the view that the country's uranium should be exploited for its own benefit, and not that of foreign actors' ${ }^{77}$

This begs the question, why did South Africa support India in the NSG decision if it was not intending to take advantage of India's exemption through nuclear cooperation with Mumbai? It is not that South Africa lacks in the economic pragmatism one sees in the case of Namibia. Rather, South Africa's seemingly ambivalent position towards normalising nuclear relations with India should be viewed in its broader context in order to take cognisance of several factors. These include South Africa's nuclear past, the current advanced state of its nuclear technology when compared to other African states, and South Africa's pursuit of emerging-state status through membership of the India-Brazil-South Africa Dialogue Forum (IBSA) and the Brazil-Russia-India-China-South Africa (BRICS) group of states.

As already noted, South Africa gave up its nuclear weapons as one of the first steps in the process of democratic transition. Sceptics may argue that the apartheid 
government of FW de Klerk did so more in anticipation that it would soon be replaced by a new government under the control of the unpredictable (and largely black-run) African National Congress (ANC). ${ }^{78}$ This is a moot point since the ANC had maintained an explicit non-proliferation stance prior to 1994. At the Conference on Nuclear Policy for a Democratic South Africa held on 11-13 February 1994 (75 days before the first democratic elections), Abdul Minty, the face of the ANC in exile on these matters, ended his keynote address to the conference as follows: 'So those who have been abroad working, hope for a free and democratic South Africa. A South Africa that will not only clean itself, but also play an international role, both to fight racism abroad, and to stop proliferation and help to produce peace. ${ }^{, 79}$ Indeed, as the first country to give up its nuclear weapons, South Africa became somewhat of a 'disarmament trendsetter' that could claim the moral high ground. As a result, South Africa was able to play a key role in negotiating the indefinite extension of the NPT in 1995, and mediated during the 2000 and 2005 NPT Review Conferences as well as being one of the leading states to bring the Pelindaba Treaty to signature. ${ }^{80}$ As a major player in the non-proliferation field compared to other African states (bar Egypt, perhaps), South Africa's nonproliferation credentials are also under greater scrutiny. This may explain, in part, South Africa's reluctance to normalise nuclear relations with India. Ironically, it is precisely its high profile that made South Africa's support of India in the NSG so significant. $^{81}$

As a member of IBSA and BRICS, South Africa has to tread lightly and diplomatically around its emerging power allies. South Africa's economic clout is not nearly that of India, Brazil, China or Russia. However, South Africa is allowed entry to their company on the premise that it is a regional powerhouse in Africa that can add its political weight to support its bigger allies in international forums, like the NSG or the United Nations Security Council (UNSC) where South Africa is currently serving as a non-permanent member (2011-2012). Despite its nonproliferation convictions, supporting India was therefore in line with the script that South Africa has to enact if it wants to keep the company of these emerging powers. ${ }^{82}$

Although the South African position reflects the tension between economic pragmatism and non-proliferation imperatives, it also illustrates issues of a postcolonial (or anti-imperialist) identity that not only informs South Africa's foreign policy, but is observable more generally in the African position on this issue. This is the subject of the next section.

\section{A common post-colonial consciousness, or a diverging one?}

India and African states often invoke their historical and ideological ties, or what this article refers to as a common post-colonial identity, to justify their increased economic relationship. ${ }^{83}$ This post-colonial identity includes a consciousness of persistent forms of colonisation, interpreting and framing these forms of subjugating power, and devising methods for their subversion and resistance. ${ }^{84}$ The Delhi Declaration that followed from the India-Africa Forum Summit in April 2008 illustrates the discourse framing Africa-India relations. The declaration talks about 'the decades-old partnership and historical and civilizational links between the African continent and India' and states in Article 1 and 2: 'We [Indian and African heads of state] recognize that Africa and India have undergone enormous positive 
changes, in particular over the last two and half decades, and that Africa and India have historically been close allies in the struggle for independence, equality, human rights, freedom and democracy.' The Summit Declaration of the India-Africa Forum Summit held in Ethiopia in 2011 repeats these themes, noting that India and Africa were 'fraternal partners and allies in the struggle for independence and achievement of self-determination' and that there exists a 'historical understanding amongst our peoples' ${ }^{85}$

The historical and political attachments between India and Africa are embodied in the Non-Aligned Movement (NAM), of which the Indian Prime Minister Jawaharlal Nehru was a founding member along with two African leaders, Ghana's former president, Kwame Nkrumah, and Egypt's Gamal Abdel Nasser. The ideational foundation of the NAM is the common history that members share in relation to the West, marginalisation, exploitation and underdevelopment (what was previously labelled a Third World consciousness). There is, however, a danger in over-romanticising India and Africa's common post-colonial identity and its relevance for an interpretation of the Pelindaba Treaty that would legitimise Africa-India nuclear cooperation.

Despite being regarded as a leader of the Developing World and having for most of the Cold War an exemplary non-aligned foreign policy, India's interpretation of post-colonialism seems to have shifted and African leaders' invocation thereof demands critical examination, especially when brought to bear on nuclear matters. Although India still uses its NAM identity when lobbying for its own interests, for example to garner support from IAEA and NSG members in the run-up to the NSG decision to exempt India from the comprehensive safeguard requirement in 2008, Marie Lall argues that India's policy has shifted. ${ }^{86}$ This view is also prevalent in the Indian media, where analysts regard non-alignment as standing in the way of India's great power pursuits and its relations with the United States. The following quote from an Indian newspaper is typical of this view: 'India today is very different from the India of the Cold War days. We are now recognised as an emerging economic power, no longer dependent on the charity of others for our economic progress. In these circumstances, does it make sense to cling to old shibboleths and slogans such as "non-aligned solidarity" in a vastly transformed world order?"87

There are other factors that provide evidence for this shift in policy, not least military cooperation between India and Israel. ${ }^{88}$ Given Egypt's concern with Israel's nuclear status, the Indo-Israeli relationship will prove problematic for NAM, possibly reducing future backing for India on nuclear matters. In fact, developments at the 2010 NPT Review Conference indicated as much: as a non-NPT member, India was not included in NAM's preparatory discussions for the Review Conference or as a part of its delegation. The NAM statement 'viewed with concern' nuclear cooperation agreements with states not under comprehensive IAEA safeguards. ${ }^{89}$ Although India was not named, the implication of this statement was clear. African states participated in the NPT Review Conference as part of the NAM bloc. The NAM position, greatly influenced by Egypt, may put African states in an increasingly awkward position vis-à-vis India.

It was noted earlier that the Pelindaba Treaty also seeks to promote human security through peaceful nuclear cooperation and that normalising India-Africa nuclear relations has the potential to advance this goal. The article now returns to this point. A consideration that African states will need to take into account, and one that India should be aware of and sensitive to, hinges on perceptions among African 
civil societies regarding the increased involvement of China and India on the African continent. There is concern that these states are engaged in a second 'scramble for Africa' ${ }^{90}$ Although India-Africa trade has increased significantly over the past decade, the composition of that trade leans toward African export of primary commodities to India and African import of manufactured goods from India. In 2006 more than $80 \%$ of African exports to India consisted of oil, gold, nuts, phosphate chemicals, and copper ore. In turn, India's exports to Africa are far more diversified with oil (not crude), medicine, motor vehicles, and rice making up $40 \%$ of exports. ${ }^{91}$ This does not bode well for the industrialisation and economic growth figures of African states, reflecting as it does the 'neo-imperialist traits' of trade relations with other developed states. Economists such as Erik Reinert have argued that specialising in the export of primary products is a significant reason why poor states remain poor. ${ }^{92}$ There is also a vast literature that warns against a resource curse when countries in Africa become dependent on commodity exports without diversifying their economies. ${ }^{93}$

Beyond economic development, the health and environmental implications of uranium mining should also be considered. Gabriella Hecht has done excellent studies that show how African uranium miners have systematically been excluded from the safety regimes that set uranium mining apart from other mining endeavours due to the risk of overexposure to radioactivity. ${ }^{94}$ The current environmental and health debates that are restricting Canadian, Australian and Indian uranium mines are seen by some mining chambers and government officials in Africa as an opportunity for African uranium supplies to fill the void. ${ }^{95}$ Should Africa-Indian nuclear cooperation be normalised, uranium mining and trade must meet the criteria of contributing to the Pelindaba Treaty's spirit of promoting human and environmental security, as well as socio-economic development, in the framework of a postcolonial consciousness. African states have an obligation to set standards to prevent the negative impacts of uranium mining.

\section{Conclusion}

No single African or AU position on the normalisation of nuclear relations with India can be discerned. There was initial political support for normalising nuclear relations with India (except from Egypt) driven by potential economic and technological benefits of such support. This pragmatic approach was also informed by the notion that if other states (the United States, France, Canada, and more) are benefitting from the NSG's India waiver, African states might as well. However, non-proliferation imperatives as codified in the Pelindaba Treaty and national laws constrain the normalisation of nuclear trade with India. This article has also argued that a post-colonial consciousness (Africa's historical relationship with India, NAM ties, South-South cooperation) frames the balancing act of these two sets of factors (economic pragmatism and non-proliferation imperatives). For Niger, for example, nuclear cooperation with India means reducing its former colonial master's hegemony over its uranium sector, letting the weight fall in favour of economic pragmatism. For Egypt, on the other hand, resisting the normalisation of nuclear relations with India signifies caution that bending the rules for India may become a precedent to bend the rules for Israel - an untenable scenario that would be counterproductive to efforts for a Middle East NWFZ. In Egypt's case, the weight thus falls on non-proliferation imperatives. For South Africa, support for India in 
the NSG means alignment with emerging powers, but by not legalising South African uranium exports to India, Pretoria suggests sensitivity toward a NAM position deeply influenced by Egypt's concerns. Thus, it seems South Africa's is a hung position.

The findings of this analysis also warrant three more critical conclusions. Firstly, Egypt's dual geopolitical location in the Middle East and Africa brings Middle Eastern geopolitics to bear on African international relations. This is clearly illustrated by the weight that Egypt's position has had on African states' political support for India on the nuclear issue. Secondly, although it has been argued that a post-colonial consciousness impacts on the position of African states, India and African states do not necessarily agree on what it means to be post-colonial. India chose to remain outside the NPT because it viewed the NPT as a form of nuclear apartheid that institutionalised a discriminatory nuclear order. India's incarnation of post-colonialism after the Cold War increasingly seems to reflect joining the club of the powerful, rather than being the leader of the 'weak'. This sense of India's rightful place at 'the table' drives the pursuit to become a recognised nuclear weapon state. In sharp contradiction, the joint NAM declaration at the NPT Review Conference in 2010 makes it clear that enlarging the club of 'nuclear haves' does not solve the problem of an unfair nuclear order.

Finally, in the light of India's interpretation of post-colonialism, the article ends with a cautionary note that it would be in the interest of African leaders to move beyond a romanticised notion of a common non-aligned identity with India, and develop a comprehensive understanding of the health, environmental and economic implications of increased uranium mining and exports to India, before they enter into agreements with India. If signatories to the Pelindaba Treaty see fit to evade the explicit prohibition on trade with non-nuclear weapon states (which India remains per the NPT definition) without an IAEA comprehensive safeguard agreement, the treaty's emphasis on human security should, at least, be taken seriously.

\section{Notes on contributor}

Joelien Pretorius is a senior lecturer in International Relations in the Department of Political Studies at the University of the Western Cape. She is also a member of the South African Pugwash branch. This article benefitted from research funded by the National Research Foundation and was originally presented at the Second Conference on the India-United States Nuclear Cooperation Agreement at the University of Reading School of Law on 16 and 17 September 2010.

\section{Notes}

1. The following sources provide a good overview of the key debates in the 'norms literature': Axelrod R, 'An evolutionary approach to norms', The American Political Science Review, 80, 4, December 1986, pp. 1095-111; Finnemore M \& K Sikkink, 'International norm dynamics and political change', International Organization, 52, 4, Autumn 1998, pp. 887-917; and Florini A, 'The evolution of international norms', International Studies Quarterly, 40, 3, Special Issue: Evolutionary Paradigms in the Social Sciences, September 1996, pp. 363-89.

2. See e.g. Southall R \& H Melber (eds), The New Scramble for Africa: Imperialism, Investment and Development in Africa. Pietermaritzburg: UKZN Press, 2009; Schoeman M, 'China and Africa: The rise of hegemony?', Strategic Review for Southern Africa, 29, 2, 2007, pp. 47-97; and Zakaria F, 'Does the future belong to China?', 
Newsweek.com, 9 May 2005, < http://www.newsweek.com/2005/05/08/does-the-futurebelong-to-china.html $>$.

3. Treaty on the Non-Proliferation of Nuclear Weapons, London/Moscow/Washington, DC, 1 July 1968.

4. See e.g. United States Congress, The US Atomic Energy Act USC 2153 (1954).

5. See IAEA, 'The Safeguards System of the International Atomic Energy Agency', $<$ http://www.iaea.org/OurWork/SV/Safeguards/documents/safeg_system.pdf $>$.

6. This is also the reason why these states, although they are de facto nuclear weapon states, cannot join the NPT as nuclear weapon states, but are required to give up their nuclear weapons and join the NPT as non-nuclear weapon states.

7. Krepon M, 'Looking back: The 1998 India and Pakistani nuclear tests', Arms Control Today, May 2008, < http://www.armscontrol.org/act/2008_05/lookingback>; for an overview of the domestic debate in India on nuclear weapons, see Weiss L, 'India and the NPT', Strategic Analysis, 34, 2, March 2010, pp. 255-71, at p. 259.

8. Bunn G \& RM Timerbaev, 'Security assurances to non-nuclear-weapon states', The Nonproliferation Review, 1, 1, Fall 1993, pp. 11-21, at p. 12.

9. Weiss L, 'India and the NPT', Strategic Analysis, 34, 2, March 2010, pp. 255-71, at p. 265; see also: International Court of Justice, 'Indian written statement submitted to the International Court of Justice on "WHO's Request for an Advisory Opinion of the International Court of Justice on Legality of Nuclear Weapons in Armed Conflict"”, 20 June 1995, < http://www.icj-cij.org/docket/files/95/8688.pdf >.

10. Suryanarayan V, 'Reflections on India's nuclear policy during the Nehru era', South Asia Analysis Group, 10 March 2010, <http://www.southasiaanalysis.org/\%5Cpapers38\% 5Cpaper3711.html >.

11. Ghengappa R, Weapons of Peace: The Secret Story of India's Quest to be a Nuclear Power. New Delhi: Harper Collins, 2000, p. 113.

12. 'PM rejects charges that N-bill would benefit US companies', BusinessGhana, 30 August 2010, < http://www.businessghana.com/portal/news/index.php?op=getNewsid $=134510>$.

13. Rahman G, 'Welcome to the nuclear club, India', Financial Times, 22 September 2008, <http://www.ft.com/intl/cms/s/0/3643cb9e-88b9-11dd-a179-0000779fd18c. html\#axzz1T01VjdR2>.

14. Fidler DP \& S Ganguly, 'India wants to join the Non-Proliferation Treaty as a weapon state', YaleGlobal, 27 January 2010, < http://yaleglobal.yale.edu/content/india-wantsjoin-non-proliferation-treaty $>$.

15. Weiss L, 'India and the NPT', Strategic Analysis, 34, 2, March 2010, pp. 255-71, at p. 265.

16. Joyner DH, Interpreting the Nuclear Non-Proliferation Treaty. Oxford: Oxford University Press, 2011, p. 71; Pant HV, 'The US-India nuclear deal: The beginning of a beautiful relationship?' Cambridge Review of International Affairs, 20, 3, September 2007, pp. $455-72$ at p. 457.

17. Israel is accused of cooperating with apartheid South Africa, North Korea with Libya and Pakistan through the AQ Khan network with among others, Al Qaida. See Polakow-Suransky S, The Unspoken Alliance: Israel's Secret Relationship with Apartheid South Africa. Cape Town: Jacana, 2010, pp. 118-53; Fitzpatrick M, Nuclear Black Markets: Pakistan, A $Q$ Khan and the Rise of Proliferation Networks. London: International Institute for Strategic Studies, 2007; Albright D \& C Hinderstein, 'Unraveling the A. Q. Khan and future proliferation networks', The Washington Quarterly, 28, 2, 2005, pp. 111-28.

18. Lall M, 'India's new foreign policy - the journey from moral nonalignment to the nuclear deal', in Lall M (ed.), The Geopolitics of Energy in South Asia. Singapore: ISEAS, 2008, <http://asiasociety.org/files/marielall_nucleardeal.pdf $>$.

19. Mattoo, A, India's nuclear deterrent: Pokhran II and beyond, New Delhi, Haranand, 1999 at 18; Weiss L, 'India and the NPT', Strategic Analysis, 34, 2, March 2010, pp. 25571.

20. Lall M, 'India's new foreign policy - the journey from moral nonalignment to the nuclear deal', in Lall M (ed.), The Geopolitics of Energy in South Asia. Singapore: ISEAS, 2008, < http://asiasociety.org/files/marielall_nucleardeal.pdf $>$. 
21. Williamson J, 'The rise of the Indian Economy', American Diplomacy. org, 11 May 2006, $<$ http://www.unc.edu/depts/diplomat/item/2006/0406/will/williamson_india.html > .

22. Lall M, 'India's new foreign policy - the journey from moral nonalignment to the nuclear deal', in Lall M (ed.), The Geopolitics of Energy in South Asia. Singapore: ISEAS, 2008, <http://asiasociety.org/files/marielall_nucleardeal.pdf $>$.

23. See $<$ http://www.nuclearsuppliersgroup.org/Leng/03-member.htm $>$ for a list of NSG member states.

24. Minty A, 'Chair's opening remarks', international seminar on the Role of Export Controls in Nuclear Non-proliferation, Vienna, Austria, 7-8 October 1997, p. 6, <http:// www.nuclearsuppliersgroup.org/Leng/PDF/SeminarControl1.pdf $>$.

25. Defined by the IAEA as 'items that can make a major contribution to an unsafeguarded nuclear fuel cycle or nuclear explosive activity, but which have non-nuclear uses as well, for example in industry'. See: NSG, 'What are the guidelines?' (INFCIRC/254, Part 2), <http://www.nuclearsuppliersgroup.org/guide.htm $>$.

26. See: IAEA, INFCIRC/254/Rev.8/Part 1a, 2006, <http://www.iaea.org/Publications/ Documents/Infcircs/2006/infcirc254r8p1.pdf $>$, for the NSG's guidelines for the export of nuclear material. On 24 June 2011, the NSG announced that it had agreed to strengthen its guidelines for the transfer of sensitive enrichment and reprocessing technologies. The new text of the guidelines is available $<$ http://www.iaea.org/ Publications/Documents/Infcircs/2011/infcirc254r10p1.pdf $>$; for a preliminary analysis on how the new guidelines might affect normalisation of nuclear trade with India, see Horner D, 'NSG revises rules on sensitive exports', Arms Control Association, 5 July 2011, < http://www.armscontrol.org/20110627/NSG_Revises_Rules_on_Sensitive_Exports > . See also: 'NSG public statement, Nuclear Suppliers Group Plenary, Noordwijk, the Netherlands, 23-24 June 2011', <http://www.nuclearsuppliersgroup.org/Leng/PRESS/ 2011-06-Public \%20statement $\% 202011 \% 20$ NSG\%20v7\%20-\%20final.pdf > .

27. Sasikumar K, 'India's emergence as a "responsible" nuclear power', International Journal, Fall 2007, < http://findarticles.com/p/articles/mi_6990/is_200710/ai_n32256973/? tag $=$ content; coll $>$.

28. See: 'Joint statement between President George W. Bush and Prime Minister Manmohan Singh', 18 July 2005, < http://georgewbush-whitehouse.archives.gov/news/releases/2005/ 07/20050718-6.html $>$.

29. VandeHei J \& D Linzer, 'U. S., India reach deal on nuclear cooperation', Washington Post, 3 March 2006, < http://www.washingtonpost.com/wp-dyn/content/article/2006/03/ 02/AR2006030200183.html>.

30. IAEA, 'Agreement between the Government of India and the International Atomic Energy Agency for the application of safeguards to civilian nuclear facilities', IAEA Information Circular, 29 May 2009, < http://www.iaea.org/Publications/Documents/ Infcircs/2009/infcirc754.pdf $>$.

31. Kimball DG, F McGoldrick L Scheinman, 'IAEA-Indian nuclear safeguards agreement: A critical analysis', Arms Control Association, 30 July 2008, < http://www.armscontrol. org/node/3205>.

32. Pretorius J, 'The nuclear non-proliferation norm and the 123 agreement', Indian Journal of International Law (forthcoming).

33. Wilson N M Martin, 'The US-India nuclear cooperation agreement: Issues for the Nuclear Suppliers Group', Policy Dialogue Brief, Stanley Foundation, 24 April 2006, <http://www.stanleyfoundation.org/publications/pdb/pdb06india.pdf $>$.

34. 'Nuclear power in India', World Nuclear Association, July 2011, < http://www.worldnuclear.org/info/inf53.html $>$.

35. Gopalakrishnan A, 'Indo-US nuclear cooperation: A nonstarter?', Economic and Political Weekly, 40, 27, 2-8 July 2005, pp. 2935-40.

36. Ramana MV, 'Nuclear power in India: Failed past, dubious future', Non-Proliferation Policy Education Centre, 21 August 2006, <http://www.npolicy.org/userfiles/image/ Nuclear $\% 20$ Power $\% 20$ in $\% 20$ India-Failed $\% 20$ Past $\%$ 20Dubious $\% 20$ Future_pdf.pdf $>$.

37. Pearson NO, 'Indian uranium need to grow 10 -fold by 2020 , nuclear power says', Bloomberg.com, 21 December 2009,<http://www.bloomberg.com/apps/news? pid $=20601091$ sid $=$ a9rxPLKedAPs\# $>$. 
38. In July 2011 the Atomic Energy Commission of India announced a major find of uranium ore. It is too early to say how this find will impact on the analysis in this section.

39. Nyimbona P, 'Regional energy cooperation and integration in Africa: Challenges and opportunities', presented by the UN Economic Commission for Africa (ECA) to the IAEA Meeting on Comprehensive Energy Planning Vienna, Austria, 30 October-3 November 2006, <http://www-tc.iaea.org/tcweb/abouttc/strategy/Thematic/ pdf/presentations/energysystemplanning/Reg_Energy-Challenges_Opportunities.pdf $>$.

40. Ibid.

41. These states have since signed or are considering signing bilateral nuclear cooperation deals with India that would allow uranium sales to India. See e.g. Jain A, 'N-deal with India: Canada beats US in Toronto', Rediff India Abroad, 17 January 2009, < http://www. rediff.com//news/2009/jan/17ndeal-with-india-canada-beats-us.htm > ; Singh G, 'After ndeal, Canadian uranium supplier sets up India office', Business News, 2 December 2009, < http://blog.taragana.com/business/2009/12/02/after-n-deal-canadian-uraniumsupplier-sets-up-india-office-5553/>; 'Uranium exports to India by Australia on cards', The Times of India, 16 December 2009, < http://timesofindia.indiatimes.com/india/ Uranium-exports-to-India-by-Australia-on-cards/articleshow/5342421.cms $>$.

42. Bagla P, 'Indian firm acquires uranium mining rights in Niger', The Hindu, 19 August 2007, <http://www.wise-uranium.org/upin.html > . URL does not link to article given here, please check

43. Hilal K \& AP Williams, as cited in 'United Nations Security Council Resolution 1540 Database: Sub-Saharan Africa', Nuclear Threat Initiative, April 2011, < http://www.nti. org/db/1540/region_subsahara.html>> .

44. Ramachandran R, 'India to tap uranium-rich Africa for fuel', The Asian Age, 5 February 2008.

45. 'India, Namibia sign uranium supply deal', Thaindian News, 31 August 2009, <http:// www.thaindian.com/newsportal/business/india-namibia-sign-uranium-supply-deal_ 100240902.html\#ixzz0hWmPViKD>.

46. Mitra D, 'Malawi, India signs three deals, show interest in joint uranium exploration', Thaindian News, 8 January 2010, < http://www.thaindian.com/newsportal/world-news/ malawi-india-signs-three-deals-show-interest-in-joint-uranium-exploration-lead_1003010 54.html>.

47. Obiko Pearson N, 'Indian uranium need to grow 10-fold by 2020 , nuclear power says', Bloomberg, 21 December 2009, <http://www.bloomberg.com/apps/news? pid $=20601091 \mathrm{sid}=\mathrm{a} 9 \mathrm{rxPLKedAPs}>$.

48. Sasi A, 'Areva offers stake to NPCIL in African uranium mines', The Hindu Business Line, 26 July 2009, < http://www.thehindubusinessline.com/2009/07/26/stories/ 2009072651160100 .htm $>$.

49. Vail J, 'Why does fungibility matter (and where did it go)?', Energy Bulletin, 27 October $2008,<$ http://www.energybulletin.net/node/47019>.

50. Sud H, 'India's quest for uranium', UPI Asia.com, 9 October 2009, < http://www.upiasia. com/Economics/2009/10/09/indias_quest_for_uranium/4071/>.

51. Gordon S, 'Implications of the sale of Australian uranium to India', Strategic and Defence Studies Centre Working Paper 410, September 2008, p. 7.

52. African Nuclear Weapon-Free Zone Treaty, Cairo, 11 April 1996. For the text of the Pelindaba Treaty see: UN General Assembly document A/50/426, electronically available from the IAEA website, <http://www.iaea.org/About/Policy/GC/GC40/Documents/ pelindab.html $>$.

53. It is difficult to use other NWFZ Treaties as precedents for the role that the Pelindaba Treaty should play to guide African states' position on India. The Rarotonga Treaty creates the South Pacific NWFZ and outlaws nuclear cooperation with non-NPT states. Member states of this Treaty have up to now treated the treaty as superseding the NSG waiver, thus choosing not to support nuclear cooperation with India. However, Australia's centre-right coalition of parties has indicated a willingness to overturn this position and export uranium to India, see: WISE Uranium Project, 'Regulatory issues: Australia', 2010, <http://www.wise-uranium.org/uregaus.html > .

54. United Nations, 'Consideration of Africa as denuclearized zone', United Nations General Assembly resolution 1652(XVI), 24 November 1961. 
55. [AHG/Res. II(I)] In 2002 the OAU transformed to African Union (AU) when the Constitutive Act (2000) of the AU entered into force. See Badejo D, The African Union. New York: Chelsea House, 2008.

56. Polakow-Suransky S, The Unspoken Alliance: Israel's Secret Relationship with Apartheid South Africa. Cape Town: Jacana, 2010.

57. 'Good guys, bad guys: Interview with Pik Botha', CNN.com-Cold War, 14 February 1999, <http://www.gwu.edu/nsarchiv/coldwar/interviews/episode-17/botha1.html > .

58. Pelindaba is the place where the uranium enrichment process for South Africa's nuclear weapons was developed and in Zulu means 'the issue is settled'.

59. Olunyeni Adeniji, former Nigerian foreign minister and chief draftsman of the Pelindaba Treaty, wrote an authoritative commentary on the negotiation process of the treaty. See: Adeniji O, 'The Treaty of Pelindaba on the African-Nuclear-Weapons Free-Zone', United Nations Institute for Disarmament Research, UNIDIR/2002/16, 2002.

60. For a timeline of events from 1960 to 2008 related to the ANWFZ, see Stott N \& A du Rand, 'The African Nuclear-Weapon-Free Zone Treaty: Abrief guide to the Pelindaba Treaty and the process of ratification', Institute for Security Studies, Pretoria, 2008, pp. 2-3.

61. By October 2010, states that have signed and ratified the treaty include: Algeria, Benin, Botswana, Burkina Faso, Burundi, Equatorial Guinea, Ethiopia, Gabon, Gambia, Guinea, Ivory Coast, Kenya, Lesotho, Libya, Madagascar, Malawi, Mali, Mauritania, Mauritius, Mozambique, Nigeria, Rwanda, Senegal, South Africa, Swaziland, Tanzania, Togo, Tunisia, Zambia, Zimbabwe, Cameroon. States that have signed, but not ratified the treaty are: Angola, Central African Republic, Cape Verde, Chad, Comoros, Republic of the Congo, Djibouti, Democratic Republic of Congo, Egypt, Eritrea, Ghana, GuineaBissau, Liberia, Namibia, Niger, Seychelles, Sierra Leone, Somalia, São Tomé and Príncipe, Sudan and Uganda.

62. Horovitz L, 'With Pelindaba, the Southern Hemisphere is free of nuclear weaponschallenges and opportunities ahead', James Martin Center for Nonproliferation Studies, 12 August 2009, <http://cns.miis.edu/stories/090812_africa_nwfz.htm > .

63. Mian Z, 'India's search for African uranium may conflict with African Nuclear-WeaponFree Zone Treaty', International Panel on Fissile Materials, 27 March 2008, <http:// www.fissilematerials.org/ipfm/pages_us_en/blog/blog/blog.php?onepost $=1$ post_id $=7>$.

64. This interpretation was proffered at a workshop hosted by the Institute for Security Studies titled 'Beyond Entry-into-Force of the African Nuclear-Weapon-Free Zone Treaty: Establishing the African Commission on Nuclear Energy', Pretoria, South Africa, 18-19 March 2010. The workshop was a high profile meeting of African diplomats working in the area of nuclear non-proliferation with some civil society organisations and was held under Chatham House rules - hence the precise source of this interpretation cannot be attributed.

65. Mian Z, 'India's search for African uranium may conflict with African Nuclear-WeaponFree Zone Treaty', 27 March 2008, < http://www.fissilematerials.org/ipfm/pages_us_en/ blog/blog/blog.php?onepost $=1$ post_id $=7>$.

66. African Union, 'Information note on the African Nuclear Weapon Free Zone Treaty (Treaty of Pelindaba)', Peace and Security Council, 53rd Meeting, 31 May 2006, Addis Ababa, Ethiopia, p. 4, < http://www.iss.co.za/uploads/53NOTE.PDF >.

67. Ibid.

68. Taken together the Treaty of Tlatelolco (Latin America), Rarotonga (the South Pacific), Bangkok (South-East Asia), the Antarctic Treaty, and the Pelindaba Treaty (Africa) covers the Southern Hemisphere. Despite the fact that not all nuclear weapon states have signed the protocols to these treaties or that their nuclear armed patrol ships still enter seas below the equator, Brazil proposed a draft resolution on a 'Nuclear Weapons Free Southern Hemisphere and Adjacent Areas' at the 51st session of the UNGA, which was approved.

69. African Union, 'Information note on the African Nuclear Weapon Free Zone Treaty (Treaty of Pelindaba)', Peace and Security Council, 53rd Meeting, 31 May 2006, Addis Ababa, Ethiopia, p. 4, < http://www.iss.co.za/uploads/53NOTE.PDF $>$. 
70. Bloomfield J \& PND Meidell, 'Nuclear weapons free zones: The untold success story of nuclear disarmament and non-proliferation', Atomic Mirror Briefing Paper, 2005, p. 1, <www.reachingcriticalwill.org/political/nwfz/atommirror.doc $>$.

71. United Nations Development Programme (UNDP), Human Development Report 1994, p. 24, < http://hdr.undp.org/en/media/hdr_1994_en_chap2.pdf $>$.

72. Pelindaba Treaty 1996 Preamble.

73. Labbe A, 'Statement on behalf of the parties and signatories that establish nuclear weapons free zones and Mongolia', delivered at the 2010 NPT Review Conference, 5 May 2010, p. 5.

74. 'African Regional Cooperative Agreement for Research, Development (AFRA)', Department of International Relations and Cooperation of South Africa, <http:// www.dfa.gov.za/foreign/Multilateral/africa/afra.htm $>$.

75. Treaty on the Non-Proliferation of Nuclear Weapons, London/Moscow/Washington, DC, 1 July 1968, Article 4.

76. The author has come to this conclusion after discussions with members of the Department of International Relations and Cooperation as well as through observation during the Institute for Security Studies workshop on the Pelindaba Treaty referred to in an earlier footnote.

77. Ramana S, 'On Indo-African nuclear trade facilitation', Institute of Peace and Conflict Studies, No 3387, 27 May 2011, accessed 24 July 2011, < http://www.ipcs.org/article/ india/on-indo-african-nuclear-trade-facilitation-3387.html $>$.

78. Pretorius J, 'Nuclear hawk to nuclear dove: South Africa's unique reversal', paper presented at the $50^{\text {th }}$ Pugwash Conference on Science and World Affairs, Cambridge, UK, 1-8 August 2000.

79. Minty A, The Nuclear Debate: Proceedings of the Conference on Nuclear Policy for a Democratic South Africa held on 11 to 13 February 1994. Cape Town: Environmental Monitoring Group and the Western Cape ANC Science and Technology Group, 1994.

80. Burgess SF, 'South Africa from the perspective of WMD supply networks: Indications and warning implications', Strategic Insights, 6, 5, August 2007; Leith R \& J Pretorius, 'Eroding the middle ground: The shift in foreign policy underpinning South African nuclear diplomacy', Politikon, 36, 3, 2009, pp. 345-61.

81. 'Boucher: IBSA's nod of Indo-US nuclear deal significant', IndianExpress, 16 September 2006, < http://www.indianexpress.com/news/boucher-ibsas-nod-of-indous-nuclear-deal/ $12776 />$.

82. Campbell K, 'New nuclear angle to IBSA talks', EngineeringNews, 19 July 2007, <www. engineeringnews.co.za/article/new-nuclear-angle-to-ibsa-talks-2007-07-19>.

83. Sharma A, 'India and Africa: Partnership in the $21^{\text {st }}$ century', South African Journal of International Affairs, 14, 2, 2007, p. 14.

84. Spivak GC \& S Harasyn, The Post-Colonial Critic:Interviews, Strategies, Dialogues. London \& New York: Routledge, 1990.

85. African Union, 'Second Africa-India Forum Summit 2011 Addis Ababa Declaration', 2011, <http://www.au.int/en/summit/africaindia/news/second-africa-india-forum-summit2011-addis-ababa-declaration $>$.

86. Lall M, 'India's new foreign policy - the journey from moral nonalignment to the nuclear deal' in Lall, M (ed), The Geopolitics Of Energy In South Asia, Singapore: ISEAS, 2008, $<\mathrm{http}$ ://asiasociety.org/files/marielall_nucleardeal.pdf $>$.

87. Partasarathy $\mathrm{G}$, 'The relevance of being "non-aligned" and the irrelevance of NAM',The Hindu Business Line, 26 July 2007, < http://www.thehindubusinessline.com/2007/07/26/ stories/2007072650160800.htm >.

88. Saint-Mézard I, 'India and Israel: An unlikely alliance', LeMonde Diplomatique, November 2010, <http://mondediplo.com/2010/11/11indiaisrael >

89. Non-Aligned Movement, 'Statement by H.E. Mr. R. M. Marty M. Natalegawa, Minister of Foreign Affairs of Indonesia (on behalf of the NAM states parties) to the NonProliferation of Nuclear Weapons Treaty (NPT) before the 2010 Review Conference of the parties to the Non-Proliferation of Nuclear Weapons Treaty', 3 May 2010, <http:// www.un.org/en/conf/npt/2010/statements/pdf/nam_en.pdf $>$. 
90. For an outline of this argument see Southall R \& H Melber (eds), The New Scramble for Africa: Imperialism, Investment and Development in Africa. Durban: UKZN Press, 2009.

91. 'The African trading relationship with India', Trade Law Centre for Southern Africa (TRALAC), 2009, <http://www.givengain.com/unique/tralac/pdf/20070717_TheAfrican TradingRelationshipwithindia.pdf $>$; Broadman HG, Africa's Silk Road: China and India's new economic frontier, Washington: The World Bank, 2007, at 121-123..

92. Reinert ES, How Rich Countries Got Rich and Why Poor Countries Stay Poor. London: Constable \& Robinson, 2007.

93. See for example Robinson JA, R Torvik \& T Verdier 'Political foundations of the resource curse', Journal of Development Economics, 79, 2006, pp. 447-68.

94. Hecht G, 'Africa and the nuclear world: Labor, occupational health, and the transnational production of uranium', Comparative Studies in Society and History, 51, 4, 2009, pp. 896-926; Hecht G, 'Nuclear ontologies' Constellations, 13, 3,September 2006, pp. 320-31; Hecht G, 'Negotiating global nuclearities: Apartheid, decolonization, and the Cold War in the making of the IAEA', in Krige J \& K Barth (eds), 'Global power knowledge: Science, technology, and international affairs', Osiris 21, July 2006, pp. 25-48.

95. Ruffini A, 'Uranium plays in Africa: African uranium miners plan to meet growing world demand for nuclear energy', Engineering and Mining Journal, December 2009, pp. $76-78$. 